\title{
Perianal Traumatic Myiasis in a Goat Caused by Wohlfahrtia magnifica (Schiner 1862) (Diptera: Sarcophagidae) in Konya Province of Turkey
}

\author{
Dilge Sila Davulcu $^{1 *(1)}$, Sule Yilmaz ${ }^{1}$, Onur Ceylan ${ }^{2}$, Bilal Dik ${ }^{2}$ \\ ${ }^{1}$ Institute of Health Science, Selcuk University, Konya, Turkey \\ ${ }^{2}$ Department of Parasitology, Faculty of Veterinary Medicine, Selcuk University, Konya, Turkey
}

\begin{abstract}
Introduction: The infestation of live humans and animals with dipterous larvae is called Myiasis. These larvae feed on the living or dead tissues, body fluids, and ingested foods of hosts at least for a certain period in myiasis cases.

Case Presentation: During clinical examination, several larvae were detected in the perianal area of a goat at Selcuk University, Faculty of Veterinary Medicine, Internal Medicine Clinics. All visible larvae were cleaned by the clinician with the help of forceps. Ivermectin administered against larvae possibly penetrated deep into the wound. A topical antibiotic was also applied, and the wound was washed with an antiseptic solution. Several larvae were preserved in tubes including ethanol (70\%) and transferred to parasitology laboratory. Firstly, the larvae were incised with a scalpel and cleared in potassium hydroxide (10\%). Then, they were rinsed in distilled water, put into $70 \%$ ethanol for dehydration, and stored in $99 \%$ ethanol until dissection. The larvae were morphologically examined under a stereo microscope and dissected. The larvae were identified as third instar larvae of Wohlfahrtia magnifica according to the morphological characteristics of cephalo-pharyngeal skeleton, anterior spiracles, and peritremes.

Conclusion: It should be kept in mind that in myiasis cases, early diagnosis is a very important factor in preventing deep tissue loss.

Keywords: Perianal myiasis, Goat, Larvae, Wohlfahrtia magnifica, Turkey
\end{abstract}

Received: July 15, 2020, Accepted: September 9, 2020, ePublished: October 14, 2020

\section{Introduction}

Myiasis is the infestation of live humans and animals with dipterous larvae (1). Myiasis caused by fly larvae can be classified into 3 types including obligatory, facultative, and accidental. Myiasis can be clinically classified as cutaneous, traumatic, intestinal, ocular, vulvar, and urinary myiasis according to the location of the larvae (2). Although many dipteran species can cause myiasis in animals, the genera commonly detected in myiasis cases of goats and sheep belong to Calliphoridae, Sarcophagidae, Oestridae, Hypodermatidae, and Gasterophilidae families (3)

Wohlfahrtia magnifica (Schiner, 1862), an obligate parasite, is one of the most well-known agents of myiasis in the Palaearctic zone (4). Infestation occurs between late spring and early autumn when the flies are active. Sarcophagid flies, especially W. magnifica, are generally attracted by the odors of feces and decaying organic matters, where they deposit larvae or eggs (1).

Larviparous flies put their larvae on skin, wounds, or natural body openings (mouth, nose, eyes, ear, genital organs, and anus) of humans and animals (3). As a result of intoxication, septicemia and deaths can occur in animals caused by enzymes secreted by the larvae and the toxic substances form in the affected areas (1). Additionally, the larvae cause serious tissue damage depending on their movements and excretions (3).

In the following report, we described a case of myiasis caused by $W$. magnifica in a goat which was transferred to Selcuk University, Veterinary Faculty, Internal Medicine Clinic in December 2020 and discussed its clinical presentation, as well as response to treatment.

\section{Case Presentation}

In December 2020, a 1-year-old goat was transferred to Selcuk University, Veterinary Faculty, Internal Medicine Clinic with the complaint of diarrhea, and 40 larvae were detected in the perianal area during the clinical examination. All visible larvae were collected using fine forceps. Ivermectin subcutaneously administered against larvae possibly penetrated deep into the wound. A topical antibiotic was also applied, and the wound was washed 
with an antiseptic solution. The larvae were preserved in tubes including $70 \%$ ethanol until species identification. Firstly, the larvae were incised (ventral side between abdominal segments three and five) with a scalpel and cleared in $10 \%$ potassium hydroxide $(\mathrm{KOH})$ at room temperature for a day. Then, they were rinsed in distilled water to remove $\mathrm{KOH}$. Subsequently, the larvae were transferred to $70 \%$ ethanol about 24 hours for dehydration and preserved in $99 \%$ ethanol until dissection. The larvae were morphologically examined and dissected under a stereo zoom microscope. Then, they were mounted on slides using Canada balsam and a coverslip. The larvae were identified as third instar larvae of $W$. magnifica according to the morphological characteristics of cephalopharyngeal skeleton, anterior spiracles, and peritremes (Figure 1).

\section{Discussion}

Wohlfahrtia magnifica and Lucilia sericata are the dominant dipteran fly species causing traumatic myiasis in animals and humans (5). W. magnifica is one of the most significant etiological agent of myiasis belonging to the Sarcophagidae family, and this obligatory myiasis causes serious lesions by damaging healthy tissues of hosts $(6,7)$. In contrast to the species causing facultative myiasis, $W$. magnifica may infest animals and humans without any predisposing conditions (8). In fact, if left untreated, myiasis caused by $W$. magnifica can produce several larvae within a few days, resulting in deep wounds (4).

There are many studies regarding myiasis caused by $W$. magnifica in animals worldwide (9-11). Several studies concerning the myiasis caused by $W$. magnifica in animals and humans have also been reported in Turkey. A case of gingival myiasis in a lamb (12) and a case of traumatic myiasis in dogs $(13,14)$ caused by $W$. magnifica were detected in Turkey. Cases of aural myiasis (15-17) and cutaneous myiasis (18) caused by W. magnifica were reported in humans in the country as well. As a result

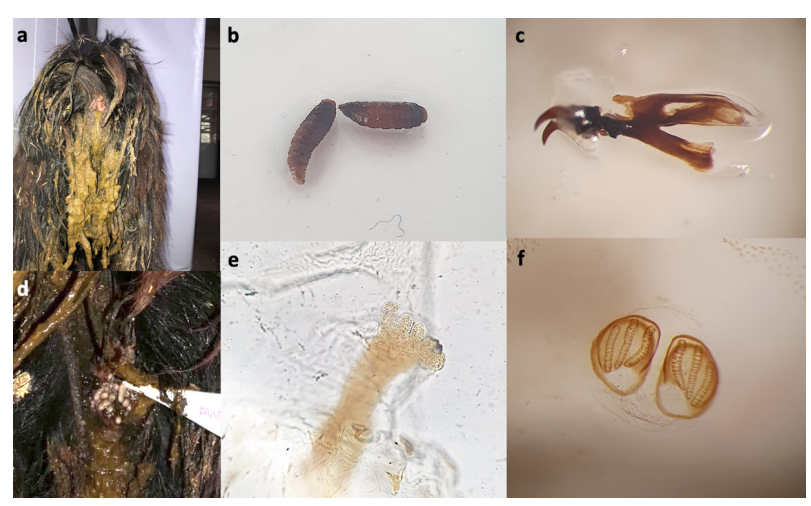

Figure 1. (a) Goat Transferred to the Clinic with the Complaint of Diarrhea, (b) the Third Instar Larvae of Wohlfahrtia Magnifica, (c) Cephalo-pharyngeal Skeleton, (d) the Larvae in Perianal Area of Goat, (e) Anterior Spiracle, (f) Peritreme. of the literature search, many other myiasis cases were detected. In these cases, W. magnifica larvae were found in the vulva of horses and sheep, genital organs of female camels, the mouth of humans and the wings of geese (1923).

In a study conducted by Dik et al, 28 animals were clinically examined and 15 of them were found to be infested with W. Magnifica larvae. It was reported that the location of myiasis can be variable according to the animal that the larvae infest. For example, traumatic myiasis was detected in different parts of the body of 8 dogs (one of them is perianal myiasis), traumatic myiasis in the interdigital region in a cattle, perianal myiasis in a sheep, traumatic myiasis in the neck of a goat, and aural myiasis in two people (5). In another study, myiasis caused by $W$. magnifica were found in the tail and nipple area of 2 goats (24). In another study conducted in Israel, 3 of the 8 goats were found to be infested with Przhevalskiana silenus and 5 of them with W. magnifica (recorded on the hoof, sternum, ear, and perianal area) (25).

Myiasis is a major animal welfare problem causing severe pain and suffering in goats and, if untreated, may cause severe tissue injury, reproduction and productivity losses, and even death $(26,27)$. Usually, there are a small number of larvae in W. magnifica infestation; however, they create large wounds in the host that can cause serious problems (11). In a study, impaired general condition and unwillingness to move were observed in a goat infested with W. magnifica larvae. The larvae had completely filled the intestinal lumen and urinary difficulty was observed due to the presence of larvae in the vulva (28). Wohlfahrtia magnifica larvae are frequently localized in natural body orifices (26), and it has been noted that wounds are not prerequisites for infestation with $W$. magnifica as adult female flies can be attracted by volatile products of vaginal discharges or urine (27).

Myiasis is of veterinary importance. It can cause yield decrease, economic losses, and even death by causing irritation, intoxication, septicemia, shock, and secondary infections in animals. Considering that myiasis can cause these problems, the first thing that comes to mind is the fight against dipteran flies, but this is very difficult. For the prevention of myiasis, it is necessary to remove the dumps, keep the garbage in closed areas, destroy animal carcasses, treat the wounds of animals and dispose of the other organic materials, which are the ideal breeding places for flies. More importantly, improving the care and feeding conditions of the animals should be an important factor. The animal owners or shelter staff should observe the general hygiene of the animal and pay special attention to the cleaning of natural body orifices of animals such as ears, nose, mouth, and anus, where flies can lay eggs or larvae. In addition, it should be kept in mind that in myiasis cases, early diagnosis is a very important factor in preventing deep tissue loss. 


\section{Conflict of Interests}

The authors declare no conflict of interest.

\section{Acknowledgments}

This study was approved by the Ethics Committee of Selcuk University, Veterinary Faculty, Experimental Animals Production and Research Center (Suvdamek-2021/32).

\section{References}

1. Zumpt F. Myiasis in Man and Animals in the Old World: A Textbook for Physicians, Veterinarians, and Zoologists. London: Butterworths; 1965.

2. Şaki CE. Elazığ'da köpeklerde tespit edilen travmatik myiasisler. Fırat Üniversitesi Sağlık Bilimleri Dergisi. 2004;18(1):29-33.

3. Dik B. Veteriner Entomoloji. 2nd ed. Konya, TR: Selcuk University Publishing ; 2015.

4. Hall MJ, Farkas R. Traumatic myiasis of humans and animals. In: Papp L, Darvas B, eds. Contributions to a Manual of Palaearctic Diptera. Volume 1: General and Applied Dipterology. Budapest, Hungary: Science Herald Publishing; 2000. p. 751-68.

5. Dik B, Uslu U, Işık N. Myiasis in animals and humanbeings in Turkey. Kafkas Univ Vet Fak Derg. 2012;18(1):37-42. doi: 10.9775/kvfd.2011.4654.

6. Panu F, Cabras G, Contini C, Onnis D. Human auricolar myiasis caused by Wohlfartia magnifica (Schiner) (Diptera: Sarcophagidae): first case found in Sardinia. J Laryngol Otol. 2000;114(6):450-2. doi: 10.1258/0022215001905814.

7. Uzun L, Cinar F, Beder LB, Aslan T, Altintas K. Radical mastoidectomy cavity myiasis caused by Wohlfahrtia magnifica. J Laryngol Otol. 2004;118(1):54-6. doi: 10.1258/002221504322731655.

8. Hall MJ. Trapping the flies that cause myiasis: their responses to host-stimuli. Ann Trop Med Parasitol. 1995;89(4):333-57. doi: 10.1080/00034983.1995.11812964.

9. Dehghani R, Zarghi I, Sayyedi HR. Genital myiasis of a sheep by Wohlfahrtia magnifica, in Ghamsar, Kashan, Iran. Bangladesh J Med Sci. 2014;13(3):332-5. doi: 10.3329/bjms. v13i3.15451.

10. Li Y, Li X, Liu J, Liu A, Guo P, Han Y, et al. Molecular identification and detection of Wohlfahrtia magnifica in ovine vulvar myiasis in Gansu, China. Trop Anim Health Prod. 2019;51(8):2629-34. doi: 10.1007/s11250-019-01925-y.

11. Rafinejad J, Akbarzadeh K, Rassi Y, Nozari J, Sedaghat MM, Hosseini $M$, et al. Traumatic myiasis agents in Iran with introducing of new dominant species, Wohlfahrtia magnifica (Diptera: Sarcophagidae). Asian Pac J Trop Biomed. 2014;4(6):451-5. doi: 10.12980/apjtb.4.2014c1029.

12. Aydenizöz M, Dik B. Bir kuzuda Wohlfahrtia magnifica (Diptera: Sarcophagidae)'dan kaynaklanan gingival miyaz olgusu. Turkiye Parazitol Derg. 2008;32(1):79-81.

13. Köse M, Bozkurt MF, Kartal K, Yaprakçı V. Wound myiasis by Wohlfahrtia magnifica in a dog. Bornova Veteriner Bilimleri
Dergisi. 2013;35(49):31-4.

14. Kılınç ÖO, Oğuz B, Sona A, Biçek K, Özdal N, Değer MS. Traumatic myiasis associated with Wohlfahrtia magnifica (Schiffner, 1862; Diptera: Sarcophagidae) larvae in a dog. Animal Health, Production and Hygiene. 2013;2(2):209-11.

15. Bayindir T, Miman O, Miman MC, Atambay M, Saki CE. Bilateral aural myiasis (Wohlfahrtia magnifica): a case with chronic suppurative otitis media. Turkiye Parazitol Derg. 2010;34(1):65-7.

16. Karaman E, Samasti M, Saritzali G, Ozdemir S, Halil MC, Isildak H. Otomyiasis by Wohlfahrtia magnifica. J Craniofac Surg. 2009;20(6):2123-4. doi: 10.1097/SCS.0b013e3181bec66e.

17. Yazgi $\mathrm{H}$, Uyanik $\mathrm{MH}$, Yoruk $\mathrm{O}$, Aslan I. Aural myiasis by Wohlfahrtia magnifica: case report. Eurasian J Med. 2009;41(3):194-6.

18. Kokcam I, Saki CE. A case of cutaneous myiasis caused by Wohlfahrtia magnifica. J Dermatol. 2005;32(6):459-63. doi: 10.1111/j.1346-8138.2005.tb00780.x.

19. Ciftçioğlu N, Altintaş K, Haberal M. A case of human orotracheal myiasis caused by Wohlfahrtia magnifica. Parasitol Res. 1997;83(1):34-6. doi: 10.1007/s004360050203.

20. Farkas R, Hall MJ, Kelemen F. Wound myiasis of sheep in Hungary. Vet Parasitol. 1997;69(1-2):133-44. doi: 10.1016/ s0304-4017(96)01110-7.

21. Farkas R, Hall MJ. Prevalence of traumatic myiasis in Hungary: a questionnaire survey of veterinarians. Vet Rec. 1998;143(16):440-3. doi: 10.1136/vr.143.16.440.

22. Farkas R, Képes G. Traumatic myiasis of horses caused by Wohlfahrtia magnifica. Acta Vet Hung. 2001;49(3):311-8. doi: 10.1556/004.49.2001.3.8.

23. Valentin A, Baumann MP, Schein E, Bajanbileg S. Genital myiasis (wohlfahrtiosis) in camel herds of Mongolia. Vet Parasitol. 1997;73(3-4):335-46. doi: 10.1016/s03044017(97)00127-1.

24. Sayin İpek DN, Saki CE. External myiasis on cows, sheep and goats in Diyarbakır province. Dicle Üniversitesi Veteriner Fakültesi Dergisi. 2010;1(1):1-7.

25. Schnur HJ, Zivotofsky D, Wilamowski A. Myiasis in domestic animals in Israel. Vet Parasitol. 2009;161(3-4):352-5. doi: 10.1016/j.vetpar.2009.01.026.

26. Sotiraki S, Hall MJR. A review of comparative aspects of myiasis in goats and sheep in Europe. Small Rumin Res. 2012;103(1):75-83. doi: 10.1016/j.smallrumres.2011.10.021.

27. Farkas R, Hall MJ, Bouzagou AK, Lhor $Y$, Khallaayoune $K$. Traumatic myiasis in dogs caused by Wohlfahrtia magnifica and its importance in the epidemiology of wohlfahrtiosis of livestock. Med Vet Entomol. 2009;23 Suppl 1:80-5. doi: 10.1111/j.1365-2915.2008.00772.x.

28. Gaglio G, Brianti E, Abbene S, Giannetto S. Genital myiasis by Wohlfahrtia magnifica (Diptera, Sarcophagidae) in Sicily (Italy). Parasitol Res. 2011;109(5):1471-4. doi: 10.1007/ s00436-011-2431-3.

(C) 2021 The Author(s); This is an open-access article distributed under the terms of the Creative Commons Attribution License (http:// creativecommons.org/licenses/by/4.0), which permits unrestricted use, distribution, and reproduction in any medium, provided the original work is properly cited. 